Acta vet. scand. 1964, 5, 17-23.

From the Department of Pathology, Royal Veterinary College, Stockholm.

\title{
FIBRINOUS ENDOCARDITIS IN DOGS
}

By

Tage Lundh

The site of endocarditis lesions is the basis for their classification into the two main groups, as valvular and parietal. Valvular endocarditis is by far the most common type in both human beings and animals.

Systems of classification according to the type of the lesions vary widely. In this department we have long adopted the system of division into fibrinous and fibrous endocarditis with subdivision of fibrinous endocarditis into acute and chronic forms.

Acute fibrinous endocarditis refers to endocardial deposits which consist mainly of fibrin and which show few or no signs of organisation, i. e. denotes fresh inflammatory changes. The term chronic fibrinous endocarditis implies that organisation of the fibrin is under way although the degree of organisation can vary, is never total, and there are invariably fibrin deposits on the surface. If the changes are solely those of fibrosis, they are classified as fibrous endocarditis and, of course, are chronic. This report is concerned only with fibrinous endocarditis in dogs. The other main type represented in the autopsy material of the department, fibrous endocarditis, will be left out for the time being.

Endocarditis of the type referred to here as fibrinous was observed by Schornagel (1936) in 2.27 per cent of about 4.500 dogs autopsied. He classified them as verrucous and ulcerative. The lesions were limited to the left half of the heart in 82.4 per cent of the animals, to the right half in 3.5 per cent, and present on both sides in 14.1 per cent. Bacteriological examination of the lesions in 31 dogs demonstrated streptococci in 20, diplococci in six, staphylococci in three, and a mixed flora in two. 
Winquist (1945) recorded fibrinous endocarditis in 0.74 per cent of $5.217 \mathrm{dog}$ autopsies. The lesions involved the mitral valve in 61.4 per cent, the aortic valves in 36.4 per cent, and the tricuspid valve in 9.1 per cent. No instance of endocarditis involving the pulmonary valves was observed. Parietal endocarditis, most often on the right side, was found in about 8 per cent of the dogs. The lesions in 21 animals were examined bacteriologically; streptococci were isolated from ten valves, diplococci from five, staphylococci and Pasteurella from one each, and mixed cocci from two. No specific infection could be demonstrated in two animals.

In an autopsy material of about 600 dogs and cats Shouse and Meier (1956) observed 27 dogs and 13 cats with acute vegetative endocarditis, a diagnosis which apparently corresponds to what is referred to here as fibrinous endocarditis. In the $\mathbf{2 6}$ dog hearts for which details are given, the lesions were limited to the mitral valve in sexteen, to the aortic valves in four and the tricuspid in two. In the other hearts the endocarditis involved more than one set of valves but in no instance affected the pulmonary valves. Haemolytic and non-haemolytic streptococci, staphylococci, Pseudomonas aeruginosa, and Escherichia coli were isolated from the lesions.

\section{AUTOPSY SURVEY}

Fibrinous endocarditis in horses, cattle, pigs, and dogs encountered in the autopsy material of this department for the period 1919 to 1944 has been covered by Winquist. The material presented now is limited to fibrinous endocarditis in dogs and the period 1937 to 1961 , i. e. overlapps to some extent with that of Winquist.

From 1937 to 1961 there were 11,574 dog autopsies (50.51

per cent males, 49.49 per cent females). Fibrinous endocarditis was observed in 67 of these dogs $(49.25$ per cent males, 50.75 per cent females) to give an overall incidence of 0.58 per cent. In five of these animals the endocarditis was completely or nearly completely parietal in the left ventricle (three dogs), the right ventricle (one $\operatorname{dog}$ ) or the right atrium (one dog). The endocarditis lesions in the other 62 dogs were valvular and only exceptionally and then only slightly extended to the parietal endocardium. 
The valves involved were

\begin{tabular}{|c|c|c|c|c|c|}
\hline mitral & \multicolumn{2}{|c|}{$34 \mathrm{dogs}$} & $(54.8$ & pe & ent) \\
\hline aortic & 12 & , & (19.4 & , & „) \\
\hline tricuspid & 4 & , & $(6.5$ & , & , ) \\
\hline oulmonary & $\mathbf{0}$ & , & & & \\
\hline itral + aortic & 8 & , & $(12.9$ & , & , ) \\
\hline itral + tricuspid & 3 & „, & $(4.8$ & „, & „) \\
\hline nitral + aortic + tricuspid & 1 & „, & (1.6 & , & ,) \\
\hline
\end{tabular}

The mitral valve, then, was involved in 46 animals (74.2 per cent), the aortic valves in 21 animals ( 33.9 per cent), the tricuspid valve in 8 animals ( 12.9 per cent), and the pulmonary valves were unaffected.

The endocardial deposits - usually as single or a few thrombus-like formations ranging in size from a few $\mathrm{mm}$. to nearly two $\mathrm{cm}$. across and often undergoing early organisation - were examined bacteriologically in 42 animals, and yielded

$\begin{array}{lrl}\text { streptococci } & 22 & \text { dogs } \\ \text { staphylococci } & 4 & " \\ \text { streptococci + staphylococci } & 2 & \Rightarrow \\ \text { Escherichia coli } & 3 & " \\ \text { No significant growth } & 11 & \end{array}$

In most animals there was evidence of concomitant bacteraemia. The streptococcal group includes five dogs from the period before 1945 for which the bacteriological diagnosis was infection with diplococci. Current bacteriological usage would undoubtedly classify these organisms as streptococci.

The age distribution of the dogs with endocarditis was

\begin{tabular}{|c|c|c|c|c|c|c|c|}
\hline$<1$ & year & 2 & & ears & 1 & 10 & ears \\
\hline 1 & , & 2 & 6 & , & 2 & 11 & ", \\
\hline 2 & years & 2 & 7 & , & 6 & 12 & , \\
\hline 3 & , & 3 & 8 & ", & 8 & 13 & ", \\
\hline 4 & " & 1 & 9 & , & 7 & 14 & ", \\
\hline
\end{tabular}

The mean age for dogs with endocarditis was 8,5 years; the mean age for the entire autopsy series was 4,5 years.

More than 25 breeds were represented but none with more than four animals except for German Shepherds which accounted for 18 cases. 


\section{DISCUSSION}

The incidence of fibrinous endocarditis in the present series was 0.58 per cent, in Winquist's 0.74 per cent, and in Schornagel's 2.27 per cent. Shouse and Meier reported an incidence of 6.6 per cent for dogs and cats combined without further specification, possibly because there was not any great difference between the species. The dogs included in the present survey were examined carefully as part of a routine autopsy series but attention was not particularly focused upon endocarditis. Shouse and Meier, on the other hand, were particularly interested in endocarditis during their survey which covered a period of less than a year. Small fibrinous deposits which have scarcely or not at all begun to be organised can easily be detached during autopsy, for example while removing blood clots from the heart, and escape attention. It can be assumed, then, that the incidence in the present series was actually greater than the 0.58 per cent recorded. With knowledge of the autopsy technique employed in this department, however, one can be quite confident that the number of endocarditis lesions which can have been missed is far too few to explain the great difference in incidence between this series and Shouse and Meier's series.

In the present series, fibrinous endocarditis has predominantly involved the left side and particularly the mitral valves. Schornagel, Winquist and Shouse, Meier have made the same observation. No instance of lesions involving the pulmonary valves has been recorded.

About 75 per cent of the lesions examined have yielded bacteriological evidence of infection, particularly streptococci as was also the case in Schornagel and Winquist's series. Staphylococci came in second place. It is unlikely that the lesions in which no infection could be demonstrated were primarily abacterial. On many such occasions the presence of a putrefactive flora made a close bacteriological study impossible.

In those instances in which there was also an inflammatory process somewhere else in the body the question naturally arises whether the endocarditis was secondary or whether it was an independent lesion. For eight of the dogs in the present series, at least, it seems that the endocarditis was secondary to a primary focal infection - solitary subcutaneous or intramuscular abscesses in two dogs and prostatis in sex dogs with abscessation in four of them. In all these animals the same organism could 
be isolated from the endocardial deposits and the presumably primary foci. Shouse and Meier have also pointed out that in some dogs in their series abscesses and prostatitis could be suspected of being primary foci.

There was no evidence for sex predisposition to fibrinous endocarditis. The sexes were very nearly equally represented in both the endocarditis series and the entire autopsy material. Older dogs, however, were heavily over-represented in the endocarditis series. Fifty of 63 dogs with endocarditis were aged between seven and fourteen years (mean for the 63 dogs 8,5 years). The mean age for the entire autopsy material was 4,5 years.

Some 25 breeds were included in the endocarditis material. No single breed was represented by more than 4 animals with the exception of German Shepherds which accounted for 18 (26.9 per cent) of the 67 animals with endocarditis. Since the entire autopsy material for the period covered by this survey included 1.213 (10.5 per cent) German Shepherds, it appears that in the Stockholm area this breed has a highly significant predisposition for acute endocarditis $\left(\chi^{2}=18.8 ; \mathrm{P}<0.001\right)$.

There has been much discussion about the pathogenesis of fibrous endocarditis in dogs. It is tempting to answer the argument that fibrous endocarditis represents a healing phase of fibrinous endocarditis by saying that in that case the incidence of fibrinous endocarditis in an autopsy series ought to be high because that of fibrous endocarditis is high. Such a comparison would seem to be of doubtful pertinency since the incidence of both types of endocarditis is governed by several and often incompletely known factors. The autopsy incidences, for example, depend upon the extent to which fibrinous endocarditis contributes to the death of the animals affected and if the lesion develops into the fibrous type, the time required for this process to take place.

It is well known that fibrous endocarditis is a lesion of old dogs. Fibrinous endocarditis in the present series also affected relatively old dogs. From this it follows that the fibrous lesions, if they are a sequel to fibrinous endocarditis, must generally be relatively recent and there ought to be some histological traces of an inflammatory background. Detweiler, Hubben, and Patterson (1960) examined 39 dogs with fibrous valvular endocarditis - the term they prefer is chronic valvular fibrosis - and in no 
instance were able to demonstrate histological signs of inflammation in the affected valves. In a similar study Stünzi (1962) came to the same conclusion for the majority of the 86 dogs he examined.

The pattern of valvular involvement scarcely suggests an association between fibrinous and fibrous endocarditis. For a series of 94 dogs with chronic valvular fibrosis Detweiler (1962) found both the mitral and tricuspid valves to be involved in 47, the mitral valve alone in 46 , and the aortic valves alone in one. None of the dogs had changes involving only the tricuspid and none had changes in the pulmonary valves. This distribution pattern differs considerably from the pattern seen in the present series for fibrinous endocarditis. Fibrous endocarditis involved the tricuspid valve to a much greater extent than fibrinous endocarditis and the converse applies to the aortic valves.

\section{REFERENGES}

Detweiler, D. K., Hubben, K. and Patterson, D. F.: Survey of Cardiovascular disease in dogs - preliminary report on the first 1,000 dogs screened. Amer. J. vet. Res. 1960, 21, 329-359.

Detweiler, $D$. K.: Wesen und Häufigkeit von Herzkrankheiten bei Hunden. Zbl. VetMed. 1962, 9, 317-356.

Schornagel, H.: Endocarditis. Tijdschr. Diergeneesk. 1936, 63, 57-67, $143-153$.

Shouse, C. L. och Meier, H.: Acute vegetative endocarditis in the dog and cat. J. Amer. vet. med. Ass. 1956, 129, 278-289.

Stünzi, H.: Zur Pathogenese der Endocarditis valvularis. Schweiz. Arch. Tierheilk. 1962, 104, 135-146.

Winqvist, G.: Topografisk och etiologisk sammanställning av de fibrinösa och ulcerösa endokarditerna hos en del av våra husdjur. Skand. VetTidskr. 1945, 35, 575—585.

\section{SUMMARY}

Fibrinous endocarditis was observed in 67 ( 0.58 per cent) of $11,574 \mathrm{dog}$ autopsies. The lesions were valvular in 62 animals and parietal in five. Valvular endocarditis mainly involved the left side of the heart, particularly the mitral valve. The pulmonary valves were never involved.

The endocardial deposits in 42 animals were examined bacteriologically. Infection with streptococci could be demonstrated in more than half the dogs. Infections with staphylococci or Escherichia coli were also encountered.

There was no evidence of sex predisposition, but a distinct age predisposition; fibrinous endocarditis was most common among dogs 
seven years old and over. A breed predisposition was seen for German Shepherds.

There are reasons for believing that fibrous endocarditis is generally not a sequel to fibrinous endocarditis.

\section{ZUSAMMENFASSUNG}

Fibrinöse Endokarditiden beim Hund.

In einem Sektionsmaterial von 11574 Hunden wurden bei 67 $(0,58 \%)$ derselben fibrinöse Endokarditiden festgestellt, die in 62 Fällen valvulären und in 5 Fällen parietalen Sitz hatten. Die valvulären Endokarditiden waren hauptsächlich in der linken Herzhälfte, und zwar in erster Linie in den Mitralisklappen lokalisiert. In keinem Falle waren die Pulmonalisklappen angegriffen.

In 42 Fällen wurden die endokardialen Beläge bakteriologisch untersucht, wobei in mehr als der Hälfte der Fälle eine Infektion mit Streptokokken ermittelt wurde. Andere vorkommende Infektionskeime waren Staphylokokken und Escherichia coli.

Eine Geschlechtsdisposition betreffs der fibrinösen Endokarditiden liess sich nicht nachweisen. Dagegen lag eine deutliche Altersdisposition vor, indem dieselben am gewöhnlichsten bei Hunden vorkamen, die 7 Jahre alt und älter waren. Betreffs des Schäfers bestand eine Rassendisposition.

Der Verfasser führt Gründe gegen die Auffassung an, dass die fibröse Endokarditis im allgemeinen das Heilungsstadium der fibrinösen bilden soll.

\section{SAMMANFATTNING}

\section{Fibrinösa endokarditer hos hund.}

I ett sektionsmaterial på 11574 hundar påvisades hos $67(0,58 \%)$ fibrinösa endokarditer, vilka i 62 fall var valvulära och i 5 fall parietala. De valvulära endokarditerna var huvudsakligen lokaliserade till vänster hjärthalva och då $i$ första hand till mitralisklaffarna. Inte i något fall var pulmonalisklaffarna angripna.

I 42 fall undersöktes de endokardiala beläggningarna bakteriologiskt, varvid i drygt hälften av fallen en infektion med streptokocker påvisades. Andra infektionsämnen som förekom var stafylokocker och Escherichia coli.

Någon könsdisposition har beträffande de fibrinösa endokarditerna ej kunnat påvisas. Däremot förelåg en tydlig åldersdisposition, så att de var vanligast hos hundar som var 7 år och äldre. För schäfer förelåg en rasdisposition.

Författaren andrar skäl emot uppfattningen att de fibrösa endokarditerna $i$ allmänhet skulle vara ett avläkningsstadium till de fibrinösa. 